Leadership: Jurnal mahasiswa manajemen Pendidikan Islam

ISSN (P): 2721-7108, ISSN (E): 2715-0399

DOI : http://dx.doi.org/10.32478/leadership. v3i1.881

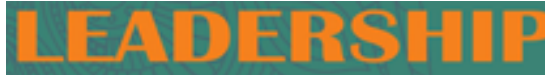

Article Type : Original Research Article

\title{
Pengelolaan Perpustakaan Sekolah Di Sekolah Menengah Pertama (SMP) Islam \\ Polehan - Malang \\ Risa Kharisma
}

STAI Ma'had Aly Al-Hikam Malang, Indonesia

Corresponding author: Email: risakharisma@gmail.com

Submission Track:

Submisson : :04-01-2022

Accept Submission : 04-01-2022

Avaliable Online : :04-01-2022

Copyright @ 2022 Author

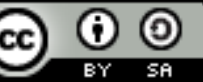

This work is licensed under a Creative Commons Attribution-ShareAlike 4.0

Abstract

This research or research focuses on describing the management of educational libraries in Islamic Junior High School Polehan - Malang. This description of the library is reviewed from several sources by explaining each discussion from the beginning of the library implementation planning process to the library evaluation process. The research method in this study is a case study, by conducting field research and collecting data from observations, documentation or interviews.

The results of this study indicate that there are activities in the management of library administration and management of library library materials. Both types of library management must begin with a clear formation of the library organizational structure which will facilitate the overall library management process. The clarity of the organizational structure of the library can be seen from the existence of the Head of the Library and Library Staff.

Management of library administration such as the vision and mission, the organizational structure, the rules, library facilities, and library services. The library management of the Islamic Middle School of Polehan - Malang has been trying to be maximized as much as possible even though there are many limitations. While the management of library library materials such as procurement of books, flow management of library materials, collection of 
Leadership: Jurnal mahasiswa manajemen pendidikan Islam

ISSN (P): 2721-7108, ISSN (E): 2715-0399

Vol. 03 No. 01 bulan Desember 2021

library materials, and storage of library materials. The management of library materials at the Islamic Middle School in Polehan - Malang during the pandemic was very different, where before the pandemic library services were carried out directly by library staff and students, then during the pandemic the guardians were allowed to come to school to borrow library books.

Keywords: Library Management, Administration, Library Materials

\begin{abstract}
Abstrak
Riset atau penelitian ini berfokus pada pendeskripsian manajemen perpustakaan pendidikan di Sekolah Menengah Pertama Islam Polehan - Malang. Pendeskripsian perpustakaan ini ditinjau dari beberapa sumber dengan menjelaskan tiap pembahasan baik dari awal proses perencanaan pelaksanaan perpustakaan hingga proses evaluasi perpustakan. Metode penelitian pada penelitian ini adalah studi kasus, dengan melakukan penelitian lapangan dan mengumpulkan data-data baik dari pengamatan, dokumentasi ataupun wawancara.

Hasil dari penelitian ini menyatakan bahwa adanya aktifitas pengelolaan administrasi perpustakaan dan pengelolaan bahan pustaka perpustakaan. kedua macam pengelolaan perpustakaan tersebut tentunya diawali dengan jelasnya pembentukan struktur organisasi perpustakaan yang nantinya akan mempermudah proses pengelolaan perpustakaan secara menyeluruh. Kejelasan struktur organisasi perpustakaan terlihat dari adanya Kepala Perpustakaan dan Staf Perpustakaan.

Pengelolaan administrasi perpustakaan seperti adanya visi dan misi, adanya struktur organisasi, adanya tata tertib, fasilitas perpustakaan, dan pelayanan perpustakaan. Pengelolaan perpustakaan SMP Islam Polehan - Malang telah berusaha dimaksimalkan sedemikian mungkin sekalipun banyak keterbatasan. Sedangkan pengelolaan bahan pustaka perpustakaan seperti pengadaan buku, alur pengelolaan bahan pustaka, koleksi bahan pustaka, dan penyimoanan bahan pustaka. Pengelolaan bahan pustaka perpustakaan SMP Islam Polehan - Malang di masa pandemi sangatlah berbeda, yang mana jika sebelum adanya pandemi pelayanan perpustakaan dilakukan secara langsung oleh staf perpustakaan dan murid, maka jika saat pandemi yang diperbolehkan datang ke sekolah untuk meminjam buku perpustakaan adalah wali murid.
\end{abstract}

Kata Kunci : Pengelolaan Perpustakaan, Administrasi, Bahan Pustaka

\title{
PENDAHULUAN
}

Pendidikan (dalam bahasa yunani "paedagogie") adalah segala usaha orang dewasa dalam pergaulannya dengan anak-anak untuk memimpin perkembangan jasmani dan rohaninya ke arah kedewasaan. Dengan kata lain pendidikan ialah pimpinan yang diberikan dengan sengaja oleh orang dewasa kepada anak-anak, dalam pertumbuhannya (jasmani dan rohani) agar berguna bagi diri sendiri dan bagi masyarakat. ${ }^{1}$ Oleh karena itu, pendidikan dapat

${ }^{1}$ M. Ngalim Purwanto, Ilmu Pendidikan Teoretis Dan Praktis (Bandung: PT Remaja Rosdakarya, 2007), hlm. 1 dan 10. 
dikatakan bahwa pendidikan merupakan unsur yang sangat penting untuk didapatkan dan dimiliki oleh setiap individu agar individu tersebut dapat beradaptasi dengan lingkungan sekitarnya serta perkembangan IPTEK (Ilmu Pengetahuan dan Teknologi) yang akan dihadapinya di masa yang akan datang.

Oleh karena itu, diperlukannya sekolah sebagai lembaga pendidikan untuk dapat memiliki manajemen perpustakaan secara baik, sehingga perpustakaan yang merupakan pusat bahan pustaka yang paling mudah dijangkau oleh seluruh warga sekolah dapat menjadi sarana yang mendukung warga sekolahnya dalam menghadapi perkembangan IPTEK. Pada perkembangan IPTEK adanya pengelolaan administrasi maupun bahan pustaka yang tersistematis dapat lebih memudahkan warga sekolah memperoleh referensi dan juga menjadikan perpustakaan dapat mengoptimalisasikan perannya dalam penyesuaian dengan perkembangan IPTEK. Perpustakaan sekolah dengan pengelolan administrasi maupun bahan pustaka yang tersistematis, secara tidak langsung juga akan dapat menunjang sekolah dalam mewujudkan visi dan misi, serta peningkatan mutu yang lebih baik tentunya.

Pada indikasi dalam pemahaman baik - buruknya kualitas dari sebuah perpustakaan tidak hanya berupa pemanfaatan perpustakaan bagi peserta didik, tetapi juga pendidik, tenaga kependidikan, dan mampu mencari, menemukan, menyaring, dan menilai informasi, khususnya peserta didik terbiasa belajar mandiri, terlatih ke arah tanggung jawab dan selalu mengikuti perkembangan IPTEK dan sebagainya. ${ }^{2}$ Dalam tata kerja perpustakaan sekolah, selalu diketuai oleh kepala perpustakaan yang membagi tugas dalam perpustakaan sekolah agar berjalan dengan sebaik-baiknya, terdapat 3 (tiga) unit kerja dalam perpustakaan sekolah, yaitu : Unit Tata Usaha, Unit Pelayanan Teknis, dan Unit Pelayanan Pembaca. ${ }^{3}$

Senada dengan yang telah dinyatakan sebelumnya mengenai pentingnya manajemen perpustakaan sekolah, baik dalam pengelolaan administarsi maupun bahan pustaka serta dalam pemahaman mengenai baik - buruknya kualitas perpustakaan, yang dapat dikatakan sebagai usaha yang dinilai mampu dipergunakan dalam menghadapi perkembangan IPTEK yang semakin pesat. Pada dasarnya dalam menghadapi perkembangan IPTEK, memang disini pusat peran perpustakaan yang dapat menjadi salah satu sarana yang sangat berpotensi untuk menghadap hal tersebut.

Peran perpustakaan dalam menumbuhkembangkan minat baca di sekolah merupakan salah satu peran terpenting adanya perpustakaan dalam lingkungan sekola, karena dalam jenjang pendidikan apapun, pihak sekolah berupaya untuk menumbuhkan rasa antusiasme membaca pada seluruh warga sekolah. Maka dari itu, perpustakaan harus mampu melakukan manajemen (pengelolaan) perpustakaan, seperti manajemen tata ruang, bahan - bahan bacaaan yang disediakan, fasilitas, dan layanan yang tetap disesuaikan dengan lingkungan atau kultur sekolah dasar. Agar perpustakaan sekolah memiliki daya tarik untuk warga sekolah mengunakan perpustakaan tersebut baik sebagai tempat belajar, pengembangan pengetahuan dan informasi, atau pun mengisi waktu luang. Dengan dilakukannya hal tersebut diharapkan perpustakaan dapat berkontribusi dalam menumbuhkembangkan minat baca para warga sekolah serta menjadikan warga sekolah sebagai masyarakat yang dapat menghadapi perkembangan IPTEK yang ada.

\footnotetext{
${ }^{2}$ Ibrahim Bafadal, Pengelolaan Perpustakaan Sekolah (Cet. VIII ; Jakarta : PT Bumi Aksara, 2011), hlm. 5 .

${ }^{3}$ Ibrahim Bafadal, Pengelolaan Perpustakaan ..., hlm. 10-11.
} 
Leadership: Jurnal mahasiswa manajemen pendidikan Islam

ISSN (P): 2721-7108, ISSN (E): 2715-0399

Vol. 03 No. 01 bulan Desember 2021

Berdasarkan fenomena diatas, maka peneliti ingin mengetahui serta dapat mendeskripsikan manajemen perpustakaan seperti apa yang dilakukan Sekolah Menengah Pertama (SMP) Islam 1 Polehan - Malang dalam pengelolaan administrasi perpustakaan dan bahan pustaka. Oleh karena itu, peneliti memillih untuk melakukan pengamatan mengenai "Manajemen Perpustakaan Di Sekolah Menengah Pertama Islam 1 Polehan - Malang".

\section{LITERATUR REVIEW}

\section{Pengertian Perpustakaan Sekolah}

Dalam Undang - undang No. 20 tahun 2003 tentang Sistem Pendidikan Nasional dalam Bab XII tentang Sarana dan Prasarana Pendidikan, menyatakan bahwa setiap satuan pendidikan formal dan non-formal menyediakan sarana dan prasarana yang memenuhi keperluan pendidikan sesuai dengan pertumbuhan dan perkembangan potensi fisik, kecerdasan intelektual, sosial, emosional, dan kejiwaan peserta didik.

Menurut Waffrord, menyatakan bahwa perpustakaan merupakan salah satu organisasi sumber belajar yang menyimpan, mengelola, dan memberikan layanan bahan pustaka baik buku maupun non buku kepada masyarakat tertentu maupun masyarakat umum. ${ }^{4}$ Berdasarkan hal tersebut, dapat dikatakan bahwa perpustakaan sekolah adalah sebagai pusat sumber belajar, sumber informasi belajar untuk warga sekolah dan berperan sebagai media belajar siswa.

Senada dengan pernyataan diatas, menurut Mbulu menyatakan bahwa keberadaan perpustakaan sekolah sangat penting dan diperlukan dengan beberapa alasan ${ }^{5}$, antara lain :

1) Perpustakaan sekolah merupakan sumber belajar di lingkungan sekolah.

2) Perpustakaan sekolah merupakan salah satu komponen dalam sistem pembelajaran.

3) Perpustakaan sekolah merupakan sumber untuk menunjang kualitas pendidikan dan pengajaran.

4) Perpustakaan sekolah sebagai laboraturium belajar yang memungkinkan peserta didik dapat mempertajam dan memperluas kemampuan membaca, menulis, berfikir, dan berkomunikasi.

Dari beberapa pendapat yang telah ada diatas, pengertian atau definisi dari perpustakaan sekolah adalah salah satu unit dari sarana dan prasarana yang wajib ada dalam lingkungan sekolah baik formal maupun non-formal yang digunakan sebagai tempat dan media yang ditujukan untuk menunjang atau meningkatkan kualitas pendidikan yang diberikan sekolah pada peserta didik dan secara tidak langsung juga dapat meningkatkan kualitas dari diri peserta didik itu sendiri.

Fungsi Perpustakaan Sekolah

Keberadaan perpustakaan sekolah merupakan sebuah keharusan bagi setiap sekolah, selain dari peran perpustakaan sekolah sebagai sumber atau media belajar dan informasi. Perpustakaan sekolah memiliki fungsi - fungsi yang setiap fungsi tersebut harus dipastikan dapat dipenuhi oleh sebuah perpustakaan.

\footnotetext{
${ }^{4}$ Darmono, Perpustakaan Sekolah (Cet. I ; Jakarta : PT Grasindo, 2007), hlm. 2.

${ }^{5}$ Darmono, Perpustakaan ..., hlm. 3.
} 
Leadership: Jurnal mahasiswa manajemen pendidikan Islam

ISSN (P): 2721-7108, ISSN (E): 2715-0399

Vol. 03 No. 01 bulan Desember 2021

Oleh karena itu, berikut akan disajikan beberapa fungsi - fungsi dari perpustakaan sekolah ${ }^{6}$, antara lain :

1) Fungsi Edukatif

Dalam fungsinya sebagai edukatif, perpustakaan sekolah tersedia buku-buku fiksi, non-fiksi. Fungsi ini bagaimana perpustakaan sekolah dapat digunakan untuk menunjang program pendidikan dan pengajaran yang ada di sekolah tersebut.

Maka melalui fungsi ini, perpustakaan sekolah dapat digunakan untuk ${ }^{7}$ :

- Agar pengguna perpustakaan sekolah mendapat kesempatan untuk mendidik diri sendiri secara kesinambungan.

- Agar membangkitkan dan mengembangkan minat yang telah dimiliki pengguna perpustakaan, dengan mempertinggi kreativitas dan kegiatan intelektual.

- Dapat mempercepat penguasaan dalam bidang pengetahuan dan teknologi baru.

Dari hal-hal tersebut perpustakaan sekolah dapat menunjang peyelenggaraan pendidikan disekolah dan membuat perpustakaan sekolah memiliki fungsi edukatif.

2) Fungsi Informatif

Perpustakaan sekolah tidak hanya harus menyediakan bahan - bahan pustaka yang berupa buku - buku, tetapi juga dapat menyediakan bahan - bahan yang non book material, seperti : majalah, buletin, surat kabar, pamflet, klimping, bahkan dapat dilengkapi dengan alat - alat pandang dengar, seperti : Komputer, LCD, Tape Recorder dan lain-lain.

Oleh karena itu, melalui fungsi ini, perpustakaan sekolah dapat digunakan untuk ${ }^{8}$

- Dapat memperoleh kesempatan untuk mendapatkan berbagai informasi yang tersedia dengan berbagai media informasi dalam rangka mencapai tujuan yang diinginkan.

- Dapat memperolah informasi untuk memecahkan masalah yang dihadapi dalam kehidupan di masyarakat.

- Dapat memperoleh dan mengolah berbagai ide dari berbagai bentuk bahan pustaka yang dibuat oleh para ahli darai berbagai bidang ilmu.

3) Fungsi Budaya

Fungsi perpustakaan sekolah yang ini sebagaimana tampak pada kegiatan didalam perpustakaan sekolah tersebut. Dalam kegiatan perpustakaan, seperti peminjaman bahan pustaka terdapat alur atau prosedur yang harus dilakukan oleh pengguna untuk meminjam bahan pustaka yang diinginkan, selain itu dalam perpustakan sekolah memiliki peraturan yang harus diikuti oleh setiap pengguna yang masuk ke perpustakaan, seperti berbagai tata tertib dalam berperilaku di perpustakaan.

Maka melalui fungsi ini, perpustakaan sekolah dapat digunakan untuk $^{9}$ :

- Mendorong tumbuhnya sikap tanggung jawab dalam menjaga apa yang menjadi tanggung jawabnya

\footnotetext{
${ }^{6}$ Ibrahim Bafadal, Pengelolaan Perpustakaan Sekolah (Cet. VIII ; Jakarta : PT Bumi Aksara, 2011), hlm. 6-8.

${ }^{7}$ Darmono, Perpustakaan Sekolah, (Cet. I ; Jakarta : PT Grasindo, 2007), hlm. 4.

${ }^{8}$ Darmono, Perpustakaan ..., hlm. 3.

${ }^{9}$ Darmono, Perpustakaan ..., hlm. 5.
} 
Leadership: Jurnal mahasiswa manajemen pendidikan Islam

ISSN (P): 2721-7108, ISSN (E): 2715-0399

Vol. 03 No. 01 bulan Desember 2021

- Menumbuhkan dan mengembangkan pola fikir yang kreativitas dalam belajar ataupun berkesenian.

- Menumbuhkan dan mengembangkan budaya baca pada pengguna terutama pada peserta didik sebagai bekal penguasaan ilmu pengetahuan yang lebih luas.

- Mengembangkan sikap dan sifat hubungan manusia yang positif ketika berinteraksi dengan orang lain.

4) Fungsi Riset

Seperti yang dinyatakan pada fungsi-fungsi sebelumnya, bahwa perpustakaan sekolah bukan hanya menyediakan bahan pustaka yang bentuk buku tetapi terdapat bebagai bentuk bahan pustaka. Dengan adanya ketersediaan bahan pustaka dalam berbagai bentuk, inilah yang dapat membuat perpustakaan sekolah difungsikan oleh guru - guru, para peserta didik dalam melakukan riset, yaitu dalam mengumpulkan data, atau keterangan - keterangan yang diperlukan dalam suatu penelitian yang dilakukan sehingga dapat menunjang kegiatan penelitian tersebut mendapatkan hasil yang maksimal.

5) Fungsi Rekreatif

Adanya perpustakaan sekolah dapat berfungsi rekreatif, artinya perpustakaan sekolah juga harus menyediakan bahan pustaka yang berniai hiburan yang tentunya tetap dalam batas hal yang dapat sesuai dengan kebutuhan pengguna dan tidak berlebihan.

Maka melalui fungsi ini, perpustakaan sekolah dapat digunakan untuk ${ }^{10}$ :

- Dapat mengembangkan minat rekreasi pengguna melalui berbagai bacaan dan pemanfaatan waktu senggang.

- Dapat digunakan dalam menunjang berbagai kegiatan kreatif serta hiburan yang positif.

\section{Pengelolaan Perpustakaan Sekolah}

Pengelolaan adalah serangkaian kegiatan terencana dan sistematis yang dilakukan secara rutin maupun berkala untuk menjaga agar sarana dan prasarana yang telah dibangun tetap dapat berfungsi dan bermanfaat sesuai dengan semestinya. Kata pengelolaan berasal dari kata dasar "kelola" yang berarti kesibukan mengurusi, menjaga atau memelihara. Dalam Kamus Besar Bahasa Indonesia disebutkan bahwa pengelolaan memiliki makna, "Proses, cara, atau perbuatan mengelola. ${ }^{11}$

1) Organisasi Perpustakaan Sekolah

Dalam pengelolaan perpustakaan sekolah merupakan aktifitas pengkoordinasian segala kegiatan yang berhubungan dengan penyelenggaraan perpustakaan sekolah. Dalam pengkoordinasian tersebut memerlukan tempat atau wadah yang menaunggi aktifitas koordinasi itu yang pada umumnya disebut dengan organisasi perpustakaan.

Dengan mengunakan organisasi perpustakaan ini kemudian dapat dibentuk struktur organisasi perpustakaan yang mampu menunjukan hubungan antara penjabat dan bidang kerja yang saling berkesinambungan dan terorganisir secara

${ }^{10}$ Darmono, Perpustakaan..., hlm. 5.

${ }^{11}$ Depdikbud, Kamus Besar Bahasa Indonesia, Jakarta: Rineka Cipta, 2002, h. 928 
Leadership: Jurnal mahasiswa manajemen pendidikan Islam

ISSN (P): 2721-7108, ISSN (E): 2715-0399

Vol. 03 No. 01 bulan Desember 2021

teratur, sehingga jelas kedudukan, wewenang, dan tanggung jawabnya masing masing. ${ }^{12}$

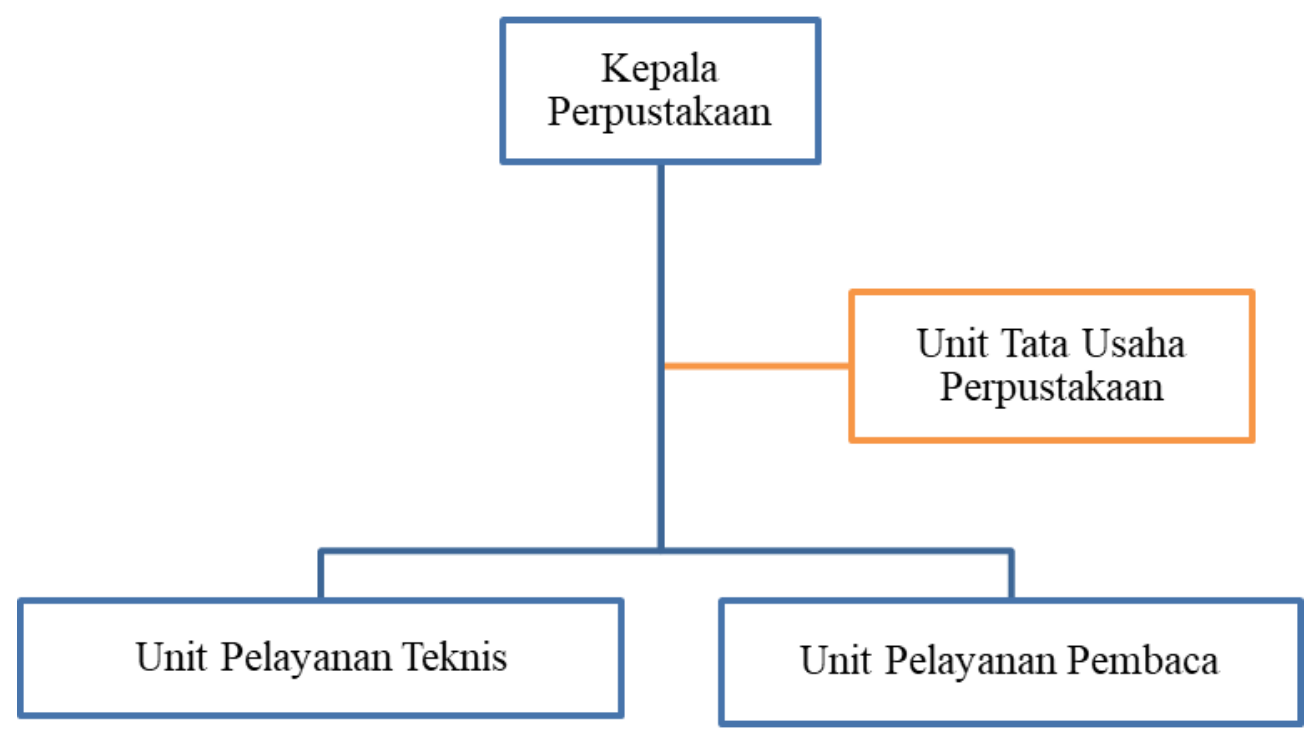

Gambar 1.1 Struktur Organisasi Perpustakaan Sekolah

Berdasarkan Gambar 1.1, struktur dasar dalam organisasi dalam pengelolaan perpustakaan sekolah terdapat 4 (empat) jabatan yang memiliki tugas masing-masing, yaitu ${ }^{13}$ :

- Kepala perpustakaan, yang bertugas untuk mengkoordinasi seluruh unit dan penyelengaraan perpustakaan sekolah. Kepala perpustakaan sekolah berusaha mengerakkan setiap unit perpustakaan dan mengarahkan segala fasilitas kerja agar perpustakaan sekolah dapat dikelola dan dijalankan secara maksimal.

- Unit tata usaha perpustakaan, yang bertanggung jawab dengan seluruh kegiatan surat-menyurat, personalia, keuangan, pengadaan dan pemeliharaan sarana dan prasarana perpustakaan sekolah.

- Unit pelayanan teknis, yang bertugas mengolah bahan - bahan pustaka secara sistematis sesuai dengan aturan yang berlaku.

- Unit pelayanan pembaca, yang bertanggung jawab dengan segala masalah peminjaman sampai pemberian bimbingan pada pengguna perpustakaan sekolah.

\footnotetext{
${ }^{12}$ Ibrahim Bafadal, Pengelolaan Perpustakaan Sekolah (Cet. VIII ; Jakarta : PT Bumi Aksara, 2011), hlm. 9.

${ }^{13}$ Ibrahim Bafadal, Pengelolaan Perpustakaan ..., hlm. 10-13.
} 
Leadership: Jurnal mahasiswa manajemen pendidikan Islam

ISSN (P): 2721-7108, ISSN (E): 2715-0399

Vol. 03 No. 01 bulan Desember 2021

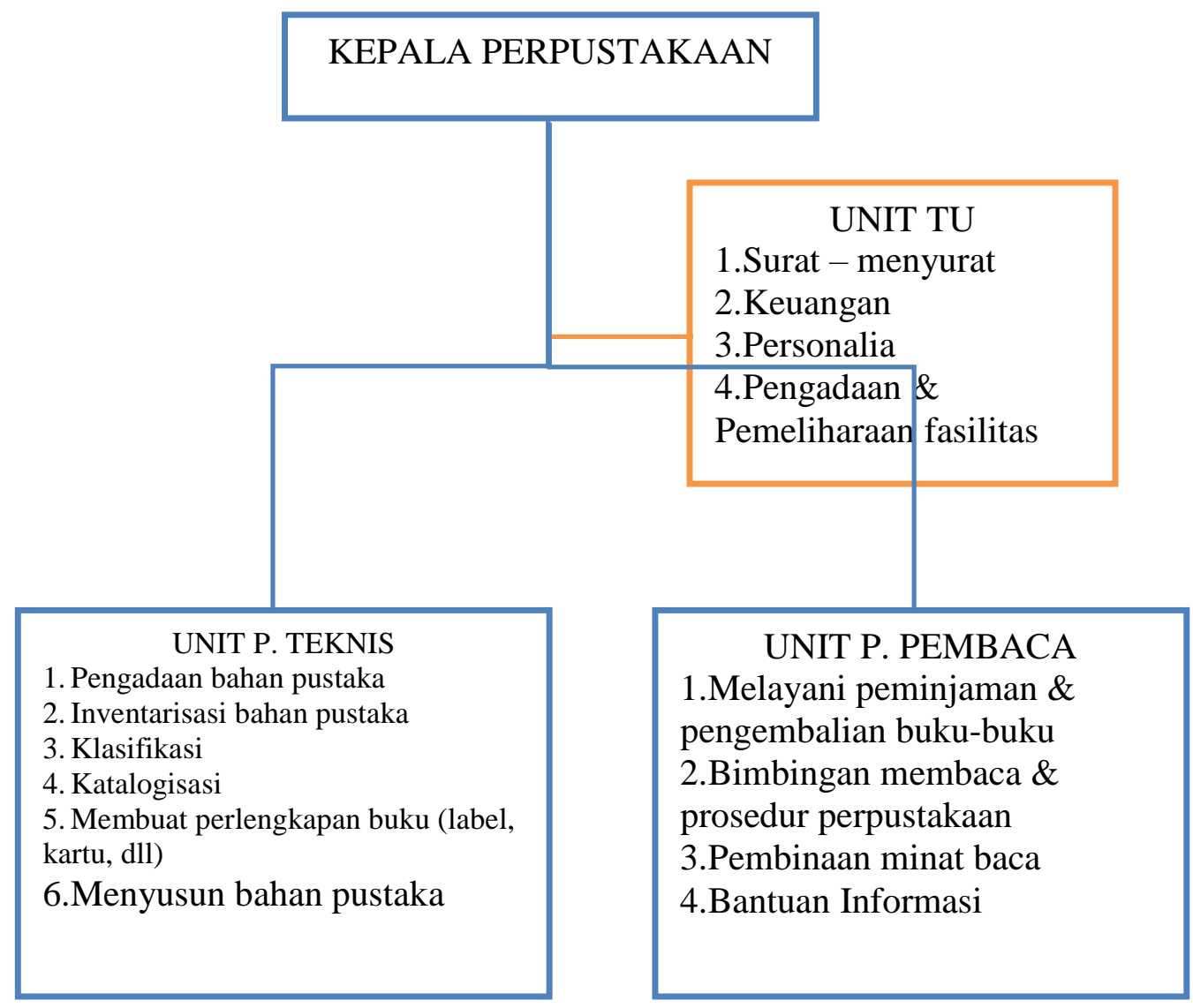

Gambar 1.2 Fungsi \& Tugas Perpustakaan Sekolah

2) Kendala Pengelolaan Perpustakaan Sekolah

Dalam praktek pengelolaan perpustakaan sekolah, belum dapat melakukan pengelolaan perpustkaan sekolah yang sistematis dan mengikuti struktur ketentuan yang ada. Menurut Darmono, terdapat 2 (dua) aspek yang menghambat berjalannya manajemen perpustakaan sekolah ${ }^{14}$, yaitu :

- Pertama, aspek struktural yaitu keberadaan perpustakaan sekolah masih kurang memperoleh perhtian dari pihak manajemen sekolah.

- Kedua, aspek teknis yaitu keberadaan perpustakaan sekolah belum ditunjang oleh aspek teknis yang dibutuhkan, seperti tenaga, dana, serta sarana dan prasarana.

Dari pernyataan tersebut, kendala yang membuat pengelolaan perpustakaan sekolah belum bisa berjalan maksimal adalah karena :

- Belum adanya kebijakkan nyata dan jelas dalam kurikulum tetntang jam khusus bagi peserta didik untuk melakukan kegiatan pemanfaatan bahan pustaka perpustakaan sekolah maupun kegitan dalam perpustakaan sekolah.

${ }^{14}$ Darmono, Perpustakaan Sekolah, (Cet. I ; Jakarta : PT Grasindo, 2007), hlm. 30-31 
Leadership: Jurnal mahasiswa manajemen pendidikan Islam

ISSN (P): 2721-7108, ISSN (E): 2715-0399

Vol. 03 No. 01 bulan Desember 2021

- Terbatasnya sumber daya manusia yang mampu mengelola perpustakaan sekolah dan mempunyai visi pengembangan yang baik.

- Kurang atau terbatasnya dana operasional untuk pengembangan perpustakaan sekolah.

- Masih kurangnya kepedulian manajemen sekolah terhadap pengembangan perpustakaan sekolah.

\section{METODE PENELITIAN}

\section{A. Pendekatan dan Jenis}

Pendekatan dalam pengamatan yang dilakukan pengamat merupakan pendekatan kualitatif. Kualitatif adalah suatu pendekatan yang bermaksud untuk memahami fenomena tentang apa yang dialami oleh objek penelitian (informan) yang bersifat alami atau natural. ${ }^{15}$ Menurut Bogdan dan Taylor mendefinisikan pendekatan kualitatif sebagai penggunaan prosedur yang menghasilkan data deskriptif berupa kata-kata tertulis atau lisan dari orang-orang dan perilaku yang dapat diamati. ${ }^{16}$

Dari pendapat tersebut, pengamat berpendapat bahwa pendekatan kualitatif merupakan pendekatan yang dilakukan berdasarkan fenomena dari tingkah laku atau suatu kejadian yang dilakukan atau dialami oleh subjek peengamatan ataupun penelitian. Berdasarkan alasan tersebut peneliti menyimpulkan bahwa pengamatan tentang manajemen perpustakaan sekolah di SMP Islam Polehan - Malang menggunakan pendekatan kualitatif dalam pengamatan yang kami lakukan.

Jenis pengamatan yang dilakukan ini merupakan studi kasus. Studi kasus adalah penelitian atau pengamatan yang dilakukan secara mendalam tentang individu atau satu kelompok dalam waktu tertentu, yang bertujuan untuk mengetahui kompleksitas dari suatu kasus. Kasus dalam penelitian ini merupakan kasus tunggal yang hanya dilakukan di SMP Islam Polehan - Malang.

Pendekatan dan jenis pengamatan ini, menggambarkan kondisi dan situasi obyek penelitian sesuai dengan keadaan lapangan, yang dalam pengamatan ini adalah manajemen perpustakaan dalam pengelolaan administrasi dan bahan pustaka di SMP Islam Polehan - Malang. Pengamat hanya akan mendeskripsikan keadaan dan fenomena yang ada dengan metode pengumpulan data kualitatif.

${ }^{15}$ Lexy J. Moleong, Metodologi Penelitian Kualitatif (Cet. XXXV; Bandung: PT. Remaja Rosdakarya, 2016), hlm. 6.

${ }^{16}$ Lexy J. Moleong, Metodologi Penelitian Kualitatif (Cet. XXXV; Bandung: PT. Remaja Rosdakarya, 2016), hlm. 4. 
Leadership: Jurnal mahasiswa manajemen pendidikan Islam

ISSN (P): 2721-7108, ISSN (E): 2715-0399

Vol. 03 No. 01 bulan Desember 2021

\section{B. Teknik Pengumpulan Data}

\section{Wawancara}

Wawancara adalah percakapan yang dilakukan oleh dua pihak, yaitu pewawancara (interviewer) yang mengajukan pertanyaan dan terwawancara (interviewee) yang memberikan jawaban atas pertanyaan itu. ${ }^{17}$ Wawancara digunakan pengamat untuk mendapat data yang berupa kata-kata guna mengali dan mengetahui ide, gagasan, maupun pandangan dari subjek pengamatan atau informan.

\section{Pengamatan (Observasi)}

Pengamatan adalah teknik pengumpulan data yang didasarkan atas pengalaman secara langsung, hal ini dilakukan untuk memperoleh keyakinan tentang keabsahan data yang telah diperoleh. Teknik pengamatan memungkinkan peneliti mampu memahami situasi-situasi yang rumit. ${ }^{18}$ Observasi digunakan untuk mendapat data yang berupa tindakan atau perilaku guna mengali dan mengetahui aktivitas dari subjek pengamatan dalam manajemen perpustakaan sekolah di SMP Islam Polehan - Malang.

\section{Dokumentasi}

Dokumentasi adalah teknik pengumpulan data berdasarkan catatan tertulis yang isinya pernyataan tertulis yang disusun oleh seseorang atau lembaga untuk keperluan pengujian suatu peristiwa, dan berguna bagi sumber data, bukti, dan informasi kealamiahan. ${ }^{19}$ Dokumentasi digunakan untuk memperoleh data yang digunakan untuk studi teks dalam mendukung hasil wawancara maupun observasi yang telah didapatkan.

HASIL

\section{A. Pengelolaan Administrasi Perpustakaan di SMP Islam Polehan - Malang}

\section{Visi dan Misi Perpustakaan}

Berdasarkan kegiatan pengamatan didapatkan informasi bahwa perpustakaan SMP Islam Polehan - Malang memiliki visi dan misinya tersendiri dari lembaganya, tetapi visi dan misi perpustakaan tetap merujuk pada terwujudnya visi dan misi SMP Islam Polehan - Malang.

a. Visi Perpustakaan

"Terwujudnya pelayanan perpustakaan terdepan dalam pembelajaran non formal serta menjadikan arsip sebagai keutuhan informasi"

b. Misi Perpustakaan

1) Meningkatkan minat baca di sekolah dan mengembangkan kreativitas siswa

${ }^{17}$ Lexy J. Moleong, Metodologi Penelitian Kualitatif (Cet. XXXV; Bandung: PT. Remaja Rosdakarya, 2016), hlm. 186.

${ }^{18}$ Lexy J. Moleong, Metodologi Penelitian ..., hlm. 174-175.

${ }^{19}$ Mahmud, Metode Penelitian Pendidikan (Cet. X ; Bandung: Pustaka Setia, 2011), hlm. 183. 
Leadership: Jurnal mahasiswa manajemen pendidikan Islam

ISSN (P): 2721-7108, ISSN (E): 2715-0399

Vol. 03 No. 01 bulan Desember 2021

2) Melestarikan kegemaran membaca demi cita-cita anak bangsa yang cerdas dan berakhlak mulia dan berjiwa santun kepada sesama manusia.

\section{Struktur Organisasi Perpustakaan}

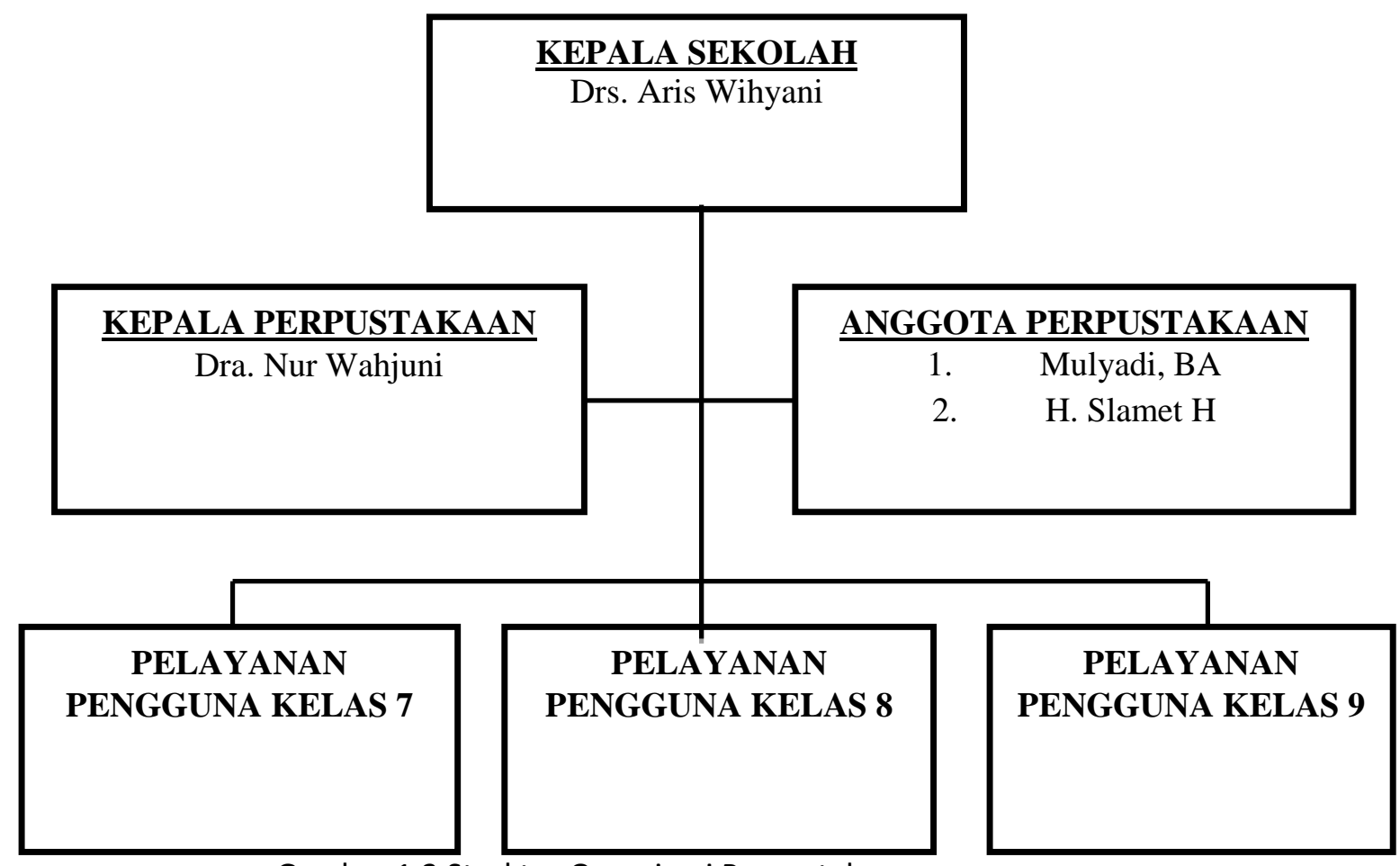

Gambar 1.3 Struktur Organisasi Perpustakaan

Berdasarkan kegiatan pengamatan didapatkan informasi bahwa seperti pada Gambar 4.1, merupakan struktur organisasi perpustakan di SMP Islam Polehan Malang. Pada kegiatan wawancara diperoleh informasi bahwa untuk kepengurusan diperankan oleh 3 (tiga) orang yaitu Ibu Dra. Nur Wahjuni selaku kepala perpustakaan, Bapak Mulyadi BA, dan Bapak $H$. Slamet $H$ selaku anggota perpustakaan.

\section{Tata Tertib Perpustakaan}

a. Peraturan yang perlu diperhatikan

1. Siswa, Guru, Karyawan, serta pengunjung lain yang memasuki ruang perpustakaan diharap melapor kepada pengelola atau petugas perpustakaan dan mengisi daftar pengunjung.

2. Di dalam ruang perpustakaan diharap menjaga ketertiban dan kesopanan supaya tidak mengganggu orang lain yang sedang membaca atau belajar.

3. Setiap peminjam buku, majalah, surat kabar, dan lain-lain harus memiliki kartu anggota perpustakaan (KAP).

4. Setiap peminjam diperbolekan mengambil sendiri buku, majalah, surat kabar yang akan dipinjam dan melaporkan kepada petugas perpustakaan. 
Leadership: Jurnal mahasiswa manajemen pendidikan Islam

ISSN (P): 2721-7108, ISSN (E): 2715-0399

Vol. 03 No. 01 bulan Desember 2021

5. Selesai membaca buku, majalah, surat kabar, dan lain-lain harus dikembalikan pada tempatnya semula.

6. Setiap peminjam harus mengembalikan pinjaman sesuai dengan waktu yang sudah ditentukan oleh petugas perpustakaan.

7. Bila ada jam kosong siswa diperbolehkan belajar di ruang perpustakaan setelah terlebih dahulu melapor kepada petugas perpustakaan.

8. Menjaga dan merawat buku, majalah, surat kabar, dan lain-lain yang dipinjam dari perpustakaan supaya tidak rusak atau kotor.

9. Apabila ada buku buku, majalah, surat kabar, dan lain-lain yang dipinjam rusak atau hilang harap segera melapor kepada petugas perpustakaan.

10. Jagalah kebersihan dan tidak membuang sampah di dalam ruang perpustakaan untuk mendapatkan kenyamanan bersama.

b. Larangan yang perlu diperhatikan

1. Tidak dibenarkan memakai topi, jaket, serta membawa tas kedalam ruang perpustakaan.

2. Dilarang membawa makanan atau minuman serta benda-benda lain yang tidak berhubungan dengan keperluan perpustakaan.

3. Dilarang makan atau minum, merokok atau al-hal lain yang bisa menodai barang-barang di dalam ruang perpustakaan serta membuat udara di dalam ruangan tidak nyaman.

4. Dilarang mencoret, menggunting, menyobek buku, majalah, surat kabar, dan lain-lain milik perpustakaan.

5. Dilarang bermain atau bergurau yang dapat mengganggu orang lain yang sedang membaca atau belajar.

6. Tidak dibenarkan menggunakan ruang perpustakaan untuk keperluan lain selain sebagai sarana pendidikan di sekolah serta untuk meningkatkan efektifitas kegiatan belajar mengajar.

7. Tidak dibenarkan menukar buku, majalah, surat kabar, dan lain-lain milik pendidikan dengan buku-buku lain tanpa seijin petugas perpustakaan, walaupun judulnya sama.

c. Sanksi pelanggaran

1. Setiap pengunjung atau peminjam yang tidak mematuhi peraturan ketertiban perpustakaan di atas akan dikenai sanksi.

2. Buku-buku, majalah, surat kabar serta barang-barang lainnya milik perpustakaan yang rusak akibat kelalaian peminjam harus dipertanggung jawabkan sesuia dengan kebijaksanaan dan ketentuan yang berlaku di perpustakaan.

3. Buku-buku yang hilang harus diganti sesuai dengan judul buku yang hilang atau diganti dengan uang yang sesuai dengan harga buku pada saat itu.

\section{Fasilitas Perpustakaan}

Berdasarkan dokumen yang didapatkan dari kegiatan pengamatan di perpustakaan SMP Islam Al-Maarif Singosari - Malang, berikut beberapa fasilitas ruang perpustakan, yaitu :

a. $84 \mathrm{~m}^{2}$ luas ruangan atau tanah ; 


\author{
b. 1437 buku paket ; \\ c. 1 unit kipas angin ; \\ d. Audio Visual terdiri dari 1 buah TV besar samsung ; \\ e. 1 unit jam dinding ; \\ f. 15 unit meja ; \\ g. 5 unit kursi ; \\ h. 1 unit tempat koran ; \\ i. 10 unit bangku untuk duduk ; \\ j. 1 unit almari kecil ; \\ k. 7 unit almari kaca ; \\ I. 6 unit rak buku ; \\ m. 2 unit almari biasa ; \\ n. 1 unit almari katalog ; \\ o. 2 unit kotak alat peraga matematika ; \\ p. 100 buku cerpen ; \\ q. 10 buku kamus ; \\ r. Perangkat VCD atau DVD, tape recorder, LCD.
}

\title{
5. Pelayanan perpustakaan
}

Berdasarkan kegiatan pengamatan didapatkan informasi bahwa perpustakaan SMP Islam Polehan - Malang dalam melakukan pelayanan dan proses peminjaman bahan pustaka menggunakan pencatatan manual oleh petugas perpustakaan. Perpustakaan SMP Islam Polehan - Malang dalam melakukan pelayanan setiap hari Senin - Sabtu, yang dimulai dari pukul 08.00 - 14.00 WIB. Kegiatan peminjaman buku perpustakaan sebelum adanya pandemi covid-19 dilakukan oleh siswa sendiri, akan tetapi di masa pandemi ini peminjaman buku dilakukan oleh orang tua siswa.

Buku yang dipinjam oleh siswa merupakan buku mata pelajaran yang berjumlah 11 (sebelas) buku yang meliputi Pendidikan Agama, Pendidikan Kewarganegaraan, Bahasa Indonesia, Matematika, IPA, IPS, Bahasa Inggris, Seni Budaya, Pendidikan Jasmani, Ketrampilan, dan Muatan Lokal. Buku 11 (sebelas) mata pelajaran tersebut dikembalikan oleh siswa ke perpustakaan saat bel berbunyi yang sesuai dengan nomor urut nya.

\section{Kendala Perpustakaan}

Terdapat beberapa kendala perpustakaan yang dialami oleh perpustakaan SMP Islam Polehan - Malang seperti diantaranya, a) kurangnya tenaga, b) petugas perpustakaan adalah dari guru yang bukan jurusan perpustakaan, c) peralatan yang terbatas, d) tenaga sangat terbatas, e) perpustakaan belum berbasis IT (IImu Teknologi), f) dana terbatas, g) minat baca siswa sangat kurang sehingga perlu guru bidang studi menggiring siswa ke perpustakaan.

\section{B. Pengelolaan Bahan Pustaka Perpustakaan di SMP Islam Polehan - Malang}

\section{Pengadaan Bahan Pustaka}

Berdasarkan kegiatan pengamatan, didapatkan informasi bahwa perpustakaan SMP Islam Polehan - Malang dalam melakukan proses pengadaan bahan pustaka terdapat hal-hal yang dilakukan seperti pengusulan bahan pustaka, pengambilan 
keputusan bahan pustaka, dan pembelian serta pelaporan pengadaan bahan pustaka.

Pengusulan bahan pustaka dilakukan oleh staf perpustakaan yang mana dalam setiap tahun ajaran baru dilakukan pendataan buku-buku yang perlu diusulkan dan dibeli. Buku-buku yang sangat dibutuhkan oleh perpustakaan SMP Islam Polehan Malang adalah buku-buku mata pelajaran dari kelas 7 (tujuh) sampai kelas 9 (sembilan), karena setiap siswa memang diwajibkan untuk meminjam buku-buku mata pelajaran ke perpustakaan. Peminjaman buku mata pelajaran oleh setiap siswa memang diharuskan, mengingat pembiayaan orang tua siswa agar lebih ringan.

Proses selanjutnya mengenai pengambilan keputusan. Pengambilan keputusan dilakukan oleh Kepala Perpustakaan, yang mana pengambilan keputusan dilakukan setelah menimbang-nimbang keperluan buku apa saja yang sangat dibutuhkan oleh siswa dan perpustakaan. pengambilan keputusan mengenai bahan pustaka tidak perlu meminta persetujuan Kepala Sekolah, dan cukup pada Kepala Perpustakaan saja.

Setelah proses pengambilan keputusan oleh Kepala Perpustakaan, kemudian adalah pembelian serta pelaporan pengadaan bahan pustaka dan dilanjutkan dengan laporan pengadaan sekaligus bukti transaksi pembelian bahan pustaka yang telah dilakukan. Berdasarkan informasi dari informan dalam pengadaan dan pembelian bahan pustaka, dilakukan oleh kepala perpustakaan dan staf perpustakaan.

\section{Alur Pengelolaan Bahan Pustaka}

Berdasarkan kegiatan pengamatan, didapatkan informasi bahwa perpustakaan SMP Islam Polehan - Malang dalam melakukan pengelolaan bahan pustaka, terutama pada bahan pustaka yang baru didapatkan dari kegiatan pengadaan, yaitu dengan melakukan proses pengkodean atau pemberian identitas pada bahan pustaka tersebut. Dalam pengkodean atau pemberian identitas bahan pustaka dilakukan oleh 2 (dua) orang yaitu : kepala perpustakaan dan 1 (satu) staf perpustakaan.

Pada proses pengkodean atau pemberian identitas perpustakaan SMP Islam Polehan - Malang menggunakan pedoman DDC (Dewey Decimal Classification) manual yang kemudian juga dilakukan pncatatan buku secara manual.

\section{Koleksi Bahan Pustaka}

Berdasarkan kegiatan pengamatan, didapatkan informasi bahwa perpustakaan SMP Islam Polehan - Malang memiliki sejumlah 1547 (seribu lima ratus empat puluh tujuh) bahan pustaka, yang terdiri dari buku teks, buku bacaan, karya tulis dan karya non - tulis. Berikut merupakan koleksi bahan pustaka, dan serial yang terdapat di Perpustakaan SMP Islam Polehan - Malang, antara lain :

Tabel 1.1 Daftar Koleksi Perpustakaan

\begin{tabular}{|c|l|c|c|}
\hline & \multicolumn{1}{|c|}{ Nama Koleksi } & $\begin{array}{c}\text { Kode / } \\
\text { Nomor }\end{array}$ & Keterangan \\
\hline a. & $\begin{array}{l}\text { Karya umum, Penelitian, } \\
\text { Psikologi, Komputer }\end{array}$ & 000 & R. Sirkulasi \\
\hline b. & Filsafat & 100 & R. Sirkulasi \\
\hline
\end{tabular}


Leadership: Jurnal mahasiswa manajemen pendidikan Islam

ISSN (P): 2721-7108, ISSN (E): 2715-0399

Vol. 03 No. 01 bulan Desember 2021

\begin{tabular}{|c|l|c|c|}
\hline c. & Agama, Budaya Islam & 200 & R. Sirkulasi \\
\hline d. & Ilmu Sosial & 300 & R. Sirkulasi \\
\hline e. & Bahasa & 400 & R. Sirkulasi \\
\hline f. & Kamus Besar & 403 & R. Sirkulasi \\
\hline g. & $\begin{array}{l}\text { Ilmu Pengetahuan Murni, } \\
\text { Fisika, Biologi, Matematika, } \\
\text { Kimia }\end{array}$ & 500 & R. Sirkulasi \\
\hline h. & $\begin{array}{l}\text { Teknologi, Pengetahuan, } \\
\text { Kedokteran }\end{array}$ & 600 & R. Sirkulasi \\
\hline i. & Seni Olahraga & 700 & R. Sirkulasi \\
\hline j. & $\begin{array}{l}\text { Sastra, Fiksi (Dongeng), } \\
\text { Non Fiksi (Buku Paket) }\end{array}$ & 800 & R. Sirkulasi \\
\hline k. & Sejarah, Geografi & 900 & R. Sirkulasi \\
\hline I. & Globe & - & R. Sirkulasi \\
\hline m. & Karya Non Tulis & - & R. Sirkulasi \\
\hline n. & Alat Peraga dan lain lain & - & R. Sirkulasi \\
\hline
\end{tabular}

\section{Penyimpanan Bahan Pustaka}

Berdasarkan kegiatan pengamatan, didapatkan informasi bahwa perpustakaan SMP Islam Polehan - Malang, dalam penyimpanan bahan pustaka menggunakan sistem manual. Pada penyimpanan bahan pustaka secara manual, dipergunakan buku induk yang berisikan seluruh data tertulis dari keseluruhan bahan pustaka yang menjadi koleksi perpustakaan. Pencatatan secara manual juga digunakan dalam administrasi keluar masuk buku.

\section{PEMBAHASAN}

\section{A. Pengertian Perpustakaan SMP Islam Polehan - Malang}

Berdasarkan teorinya, menurut Waffrord bahwa perpustakaan merupakan salah satu organisasi sumber belajar yang menyimpan, mengelola, dan memberikan layanan bahan pustaka baik buku maupun non buku kepada masyarakat tertentu maupun masyarakat umum. ${ }^{20}$ Berdasarkan hal tersebut, dapat dikatakan bahwa perpustakaan sekolah adalah sebagai pusat sumber belajar, sumber informasi belajar untuk warga sekolah dan berperan sebagai media belajar siswa.

Senada dengan teori pengertian perpustakaan yang telah disampaikan, maka SMP Islam Polehan - Malang memiliki pengertian atau penerjemahan mengenai perpustakaan nya sendiri, yaitu sesuai dengan yang tertuang dalam visi nya yang berbunyi "Terwujudnya pelayanan perpustakaan terdepan dalam pembelajaran non formal serta menjadikan arsip sebagai keutuhan informasi". Maka dari visi tersebut dapat disimpulkan bahwa perpustakaan SMP Islam Polehan - Malang ingin memberikan tidak hanya sekedar perpustakaan yang dapat digunakan siwa sebagai sarana belajar, akan tetapi sebagai

${ }^{20}$ Darmono, Perpustakaan Sekolah (Cet. I ; Jakarta : PT Grasindo, 2007), hlm. 2. 
Leadership: Jurnal mahasiswa manajemen pendidikan Islam

ISSN (P): 2721-7108, ISSN (E): 2715-0399

Vol. 03 No. 01 bulan Desember 2021

tempat siswa mengembangkan diri dan potensinya, serta sebagai tempat yang baik untuk mengarsipkan informasi.

\section{B. Fungsi Perpustakaan SMP Islam Polehan - Malang}

Adanya perpustakaan bagi sekolah adalah hal yang penting, maka terdapat beberapa fungsi perpustakaan sekolah seperti, a) fungsi edukatif, b) fungsi Informatif, c) fungsi budaya, d) fungsi riset, dan e) fungsi rekreatif. ${ }^{21}$ Perpustakaan SMP Islam Polehan Malang telah menerapkan fungsi edukatif, informatif, budaya, dan rekreatif dalam rangka menunjang proses pembelajaran murid.

\section{Pengelolaan Perpustakaan SMP Islam Polehan - Malang}

Pengelolaan adalah serangkaian kegiatan terencana dan sistematis yang dilakukan secara rutin maupun berkala untuk menjaga agar sarana dan prasarana yang telah dibangun tetap dapat berfungsi dan bermanfaat sesuai dengan semestinya. Kata pengelolaan berasal dari kata dasar "kelola" yang berarti kesibukan mengurusi, menjaga atau memelihara. Dalam Kamus Besar Bahasa Indonesia disebutkan bahwa pengelolaan memiliki makna, "Proses, cara, atau perbuatan mengelola. ${ }^{22}$

Pengelolaan perpustakaan sekolah merupakan serangkaian kegiatan terencana dan sistematis yang dilakukan secara rutin maupun berkala untuk menjaga agar sarana dan prasarana perpustakaan sekolah tetap dapat berfungsi dan bermanfaat sesuai dengan semestinya. Pengelolaan SMP Islam Polehan - Malang pada penerapan nya teradapat adanya struktur organisasi yang sangat jelas dalam pembagiannya, terdapat pula pengelolaan administrasi yang mana mengatur setiap aktivitas perpustakaan, dan ada pengelolaan bahan pustaka yang mengatur bahan pustaka dari sejak baru dibeli hingga penyimpanan dan pelayanannya.

\section{Organisasi Perpustakaan Sekolah}

Dalam pengelolaan perpustakaan sekolah merupakan aktifitas pengkoordinasian segala kegiatan yang berhubungan dengan penyelenggaraan perpustakaan sekolah. Dalam pengkoordinasian tersebut memerlukan tempat atau wadah yang menaungi aktifitas koordinasi itu yang pada umumnya disebut dengan organisasi perpustakaan.

Dengan menggunakan organisasi perpustakaan ini kemudian dapat dibentuk struktur organisasi perpustakaan yang mampu menunjukan hubungan antara penjabat dan bidang kerja yang saling berkesinambungan dan terorganisir secara teratur, sehingga jelas kedudukan, wewenang, dan tanggung jawabnya masing - masing. ${ }^{23}$ Sesuai dengan teori tersebut, maka berikut adalah struktur organisasi kepengurusan perpustakaan SMP Islam Polehan - Malang :

${ }^{21}$ Ibrahim Bafadal, Pengelolaan Perpustakaan Sekolah (Cet. VIII ; Jakarta : PT Bumi Aksara, 2011), hlm. 6-8.

${ }^{22}$ Depdikbud, Kamus Besar Bahasa Indonesia, Jakarta: Rineka Cipta, 2002, h. 928

${ }^{23}$ Ibrahim Bafadal, Pengelolaan Perpustakaan Sekolah (Cet. VIII ; Jakarta : PT Bumi Aksara, 2011), hlm. 9. 


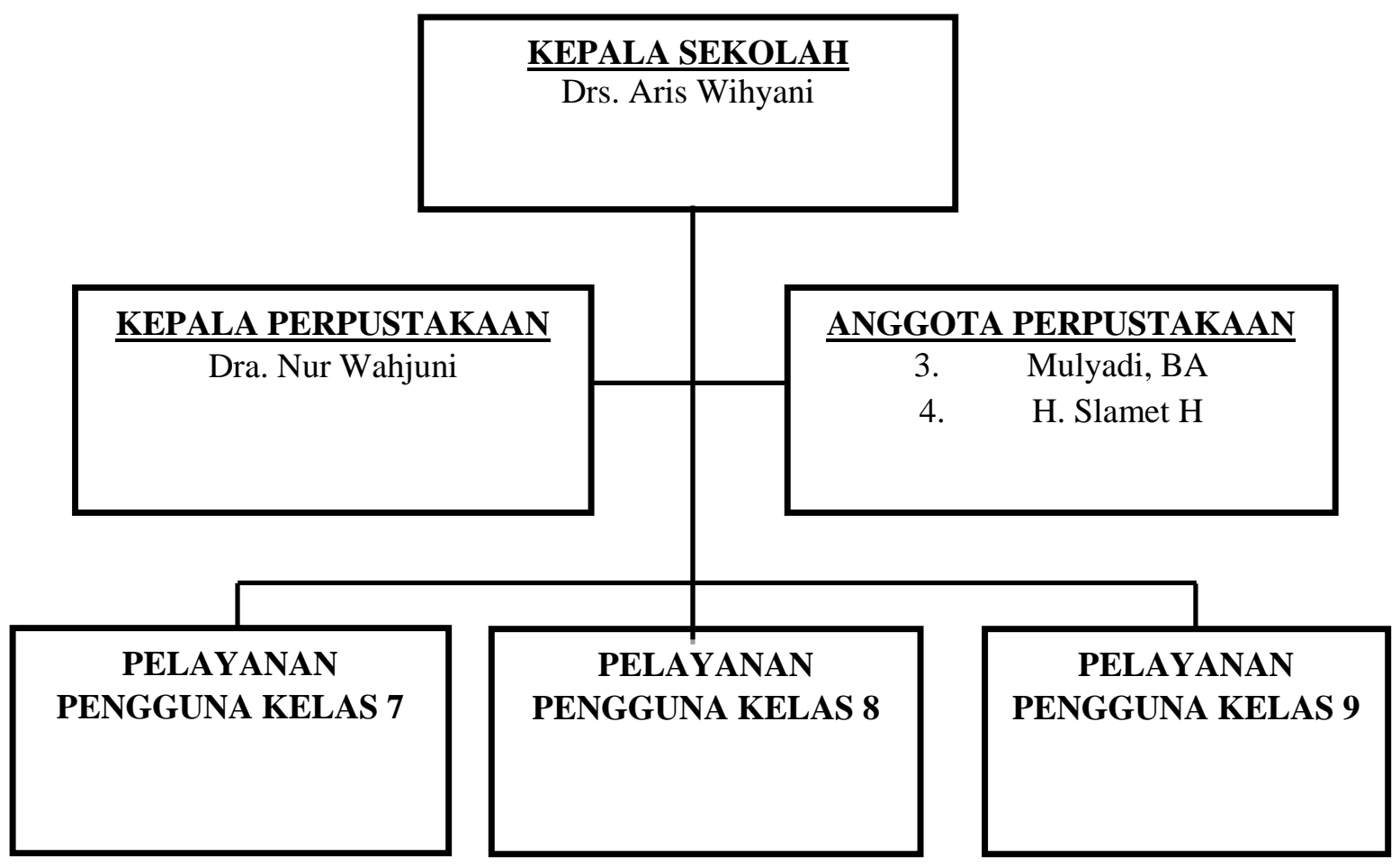

Gambar 1.4 Struktur Organisasi Perpustakaan

Gambar struktur organisasi tersebut menunjukkan bahwa terdapat Kepala Sekolah yaitu Bapak Drs. Aris Wihyani, Kepala Perpustakaan yaitu Ibu Dra. Nur Wahjuni, Anggota Perpustakaan yaitu Bapak Mulyadi, BA dan $\mathrm{H}$. Slamet $\mathrm{H}$, serta pelayanan pengguna kelas 7 (tujuh) sampai kelas 9 (sembilan).

Struktur organisasi yang telah dibuat sangatlah jelas menunjukkan bahwa adanya bagian kerja dan pekerjanya, namun dalam penerapannya tidaklah selalu sesuai dengan struktur organisasi yang telah dibuat. Hal tersebut dikarenakan sedikitnya aktifitas perpustakaan terutama dimasa pandemi.

\section{Pengelolaan Administrasi Perpustakaan SMP Islam Polehan - Malang}

Adnimistrasi adalah proses rangakian kegiatan terhadap pekerjaan pokok yang dilakukan oleh sekelompok orang secara dinamis dengan kerja sama dengan pola pembagian kerja untuk mencapai sasaran dan tujuan tertentu yang rasional secara efektif dan efisien. ${ }^{24}$

Berdasarkan teori yang telah dipaparkan, maka pengelolaan administrasi SMP Islam Polehan - Malang merupakan serangkaian proses mengolah perpustakaan oleh beberapa orang dengan pembagian kerja tertentu secara efektif dan efisien. Terdapat beberapa penjabaran dari pengelolaan administrasi perpustakaan SMP Islam Polehan - Malang :

a. Tata terbib perpustakaan

\footnotetext{
${ }^{24}$ Ismail Nawawi, Perilaku Organisasi, (Jakarta : ITS Press, 2009), hlm. 35
} 
Tata tertib perpustakaan terbagi menjadi peraturan, larangan, dan sanksi. Peraturan yang berlaku seperti diwajibkannya melapor dan mengisi daftar pengunjung bagi siapa saja yang mengunjungi perpustakaan, diwajibkannya menjaga kesopanan, diwajibkannya menjaga buku yang dipinjam, dan sebagainya. Sedangkan larangan yang berlaku di perpustakaan seperti dilarangnya membawa benda-benda yang tidak berhubungan dengan perpustakaan, dilarangnya mengganggu pengunjung lain yang sedang membaca, dilarangnya menodai barangbarang perpustakaan, dan sebagainya. Dan sanksi yang berlaku oleh perpustakaan seperti

b. Fasilitas perpustakaan

Fasilitas perpustakaan SMP Islam Polehan - Malang diantaranya seperti 1547 bahan pustaka, dua unit alat peraga matematika, meja kursi, dan sebagainya yang menunjang kelancaran kegiatan perpustakaan.

c. Pelayanan perpustakaan

Perpustakaan SMP Islam Polehan - Malang dalam melakukan pelayanan setiap hari Senin - Sabtu, yang dimulai dari pukul 08.00 - 14.00 WIB. Kegiatan peminjaman buku perpustakaan sebelum adanya pandemi covid-19 dilakukan oleh siswa sendiri, akan tetapi di masa pandemi ini peminjaman buku dilakukan oleh orang tua siswa. Setiap pelayanan pengunjung perpustakaan akan dilakukan pencatatan oleh petugas perpustakaan, dan pencatatan tersebut dilakukan secara manual.

d. Kendala perpustakaan

Terdapat beberapa kendala perpustakaan yang dialami oleh perpustakaan SMP Islam Polehan - Malang seperti diantaranya, a) kurangnya tenaga, b) petugas perpustakaan adalah dari guru yang bukan jurusan perpustakaan, c) peralatan yang terbatas, d) tenaga sangat terbatas, e) perpustakaan belum berbasis IT (IImu Teknologi), f) dana terbatas, g) minat baca siswa sangat kurang sehingga perlu guru bidang studi menggiring siswa ke perpustakaan.

\section{Pengelolaan Bahan Pustaka Perpustakaan SMP Islam Polehan - Malang}

Bahan pustaka adlah unsur penting dalam sistem perpustakaan, dimana bahan pustaka harus dilestarikan karena memiliki nilai informasi yang mahal. Bahan pustaka berupa terbitan buku, berkala (surat kabar dan majalah), dan bahan audio visual seperti audio kaset, video, slide, CD-Rom dan sebagainya).

a. Pengadaan bahan pustaka

pengadaan bahan pustaka dilakukan mulai pengusulan bahan pustaka, pengambilan keputusan bahan pustaka, hingga pembelian serta pelaporan pengadaan bahan pustaka. Pengusulan bahan pustaka dilakukan oleh staf perpustakaan pada setiap tahun ajaran baru melalui pendataan kebutuhan buku. Kemudian pengambilan keputusan diputuskan oleh kepala perpustakaan mengenai buku apa saja yang harus diadakan. Serta pembelian dan pelaporan pengadaan bahan pustaka dan dilanjutkan dengan laporan pengadaan sekaligus bukti transaksi pembelian bahan pustaka yang telah dilakukan. Berdasarkan informasi dari informan dalam pengadaan dan pembelian bahan pustaka, dilakukan oleh kepala perpustakaan dan staf perpustakaan.

b. Alur pengelolaan bahan pustaka 
Pengelolaan bahan pustaka terutama buku-buku baru adalah dilakukannya proses pengkodean atau pemberian identitas pada bahan pustaka tersebut. Dalam pengkodean atau pemberian identitas bahan pustaka dilakukan oleh 2 (dua) orang yaitu : kepala perpustakaan dan 1 (satu) staf perpustakaan. Pada proses pengkodean atau pemberian identitas perpustakaan SMP Islam Polehan - Malang menggunakan pedoman DDC (Dewey Decimal Classification) manual yang kemudian juga dilakukan pencatatan buku secara manual.

c. Koleksi bahan pustaka

Koleksi bahan pustaka perpustakaan SMP Islam Polehan - Malang seperti diantaranya, karya umum, filsafat, agama, ilmu sosial, bahasa, kamus besar, fisika, biologi, matematika, kimia, komik, seni olahraga, fiksi dan non fiksi, sejarah, geografi.

d. Penyimpanan bahan pustaka

Penyimpanan bahan pustaka perpustakaan SMP Islam Polehan - Malang menggunakan sistem manual. Pada penyimpanan bahan pustaka secara manual, dipergunakan buku induk yang berisikan seluruh data tertulis dari keseluruhan bahan pustaka yang menjadi koleksi perpustakaan. Pencatatan secara manual juga digunakan dalam administrasi keluar masuk buku.

\section{PENUTUP}

Pengelolaan perpustakaan sekolah merupakan serangkaian kegiatan terencana dan sistematis yang dilakukan secara rutin maupun berkala untuk menjaga agar sarana dan prasarana perpustakaan sekolah tetap dapat berfungsi dan bermanfaat sesuai dengan semestinya. Terdapat dua macam pengelolaan pada perpustakaan SMP Islam Polehan Malang, yaitu pengelolaan administrasi perpustakaan dan pengelolaan bahan pustaka perpustakaan. kedua macam pengelolaan tersebut berusaha untuk dimaksimalkan adanya dengan segala keterbatasan yang ada.

Pengelolaan administrasi perpustakaan merupakan serangkaian proses mengolah perpustakaan oleh beberapa orang dengan pembagian kerja tertentu secara efektif dan efisien. Terdapat beberapa penjabaran dari pengelolaan administrasi perpustakaan SMP Islam Polehan - Malang seperti tata tertib perpustakaan yang di dalamnya memuat peraturan serta larangan dan sanksi, fasilitas perpustakaan yang berisi mengenai sarana prasarana perpustakaan, pelayanan perpustakaan yang memuat mengenai aktivitas pelayanan bahan pustaka, dan kendala-kendala yang terjadi di perpustakaan.

Selain pengelolaan administrasi, terdapat pula pengelolaan bahan pustaka yang di dalamnya dapat dijabarkan seperti, a) pengadaan bahan pustaka, proses pengadaan bahan pustaka diawali dari pengusulan bahan pustaka yang dilakukan setiap tahun ajaran baru, pengambilan keputusan yang dapat dilakukan oleh Kepala Perpustakaan, serta pembelian bahan pustaka yang telah disetujui, b) alur pengelolaan bahan pustaka, yang mana saat buku datang maka akan dilakukan pendataan secara manual di buku induk dan kemudian dilakukan pengkodean, c) koleksi bahan pustaka, koleksi bahan pustaka perpustakaan SMP Islam Polehan - Malang seperti diantaranya, karya umum, filsafat, agama, ilmu sosial, bahasa, 
Leadership: Jurnal mahasiswa manajemen pendidikan Islam

ISSN (P): 2721-7108, ISSN (E): 2715-0399

Vol. 03 No. 01 bulan Desember 2021

kamus besar, fisika, biologi, matematika, kimia, komik, seni olahraga, fiksi dan non fiksi, sejarah, geografi, dan d) penyimpanan bahan psutaka, menggunakan sistem manual. Pada penyimpanan bahan pustaka secara manual, dipergunakan buku induk yang berisikan seluruh data tertulis dari keseluruhan bahan pustaka yang menjadi koleksi perpustakaan. Pencatatan secara manual juga digunakan dalam administrasi keluar masuk buku.

\section{DAFTAR RUJUKAN}

Purwanto, Ngalim, M. 2007. Ilmu Pendidikan Teoretis Dan Praktis. Bandung : PT Remaja Rosdakarya

Bafadal, Ibrahim. 2011. Pengelolaan Perpustakaan Sekolah. Cet. VIII . Jakarta : PT Bumi Aksara.

Darmono. 2007. Perpustakaan Sekolah. Cet. I. Jakarta : PT Grasindo

Moleong, J., Lexy. 2016. Metodologi Penelitian Kualitatif. Cet. XXXV. Bandung: PT. Remaja Rosdakarya.

Depdikbud. 2002. Kamus Besar Bahasa Indonesia. Jakarta : Rineka Cipta.

Nawawi, Ismail. 2009. Perilaku Organisasi. Jakarta : ITS Press. 